\title{
NOTES ON PHYTOSOCIOLOGY OF GUNIPERUS EXCELSA IN MACEDONIA (SOUTHERN BALKAN PENINSULA)
}

\author{
Vlado MATEVSKI ${ }^{1}$, Andraž ČARNI $^{2,3, *}$, Mitko KOSTADINOVSKI ${ }^{1}$, \\ Aleksander MARINŠEK ${ }^{2}$, Ladislav MUCINA ${ }^{4}$, Andrej PAUŠIČ ${ }^{2} \&$ Urban ŠILC ${ }^{2}$
}

\begin{abstract}
Funiperus excelsa is an East Mediterranean species found also in marginal, sub-mediterranean regions of the southern part of the Balkan Peninsula. It prefers shallow soils in the warmest habitats of the zone of thermophilous deciduous forests. In the past the rank of alliance and the name of funiperion excelsae-foetidissimae have been suggested for the vegetation dominated by funiperus excelsa in the Balkan Peninsula. In this paper we present the valid description of the alliance in accordance with the International Code of Phytosociological Nomenclature. The validation of the funiperion excelsae-foetidissimae required description of a new association - the Querco trojanae-funiperetum excelsae. The funiperion excelsae-foetidissimae is classified within the order of Quercetalia pubescentis Klika 1933 (the Quercetea pubescentis Doing-Kraft ex Scamoni et Passarge 1959).

Keywords: East Mediterranean, forest, Funiperion excelsae-foetidissimae, nomenclature, Quercetea pubescentis, vegetation.
\end{abstract}

\section{Izvleček}

Funiperus excelsa je vzhodnomediteranska vrsta, ki jo najdemo tudi v submediteranskih predelih južnega Balkana. Najdemo jo lahko na najtoplejših rastiščih na plitvih tleh v območju termofilnih listopadnih gozdov. V preteklosti so na Balkanskem polotoku vegetacijo, kjer dominira vrsta funiperus excelsa, uvrščali v zvezo $\mathcal{f} u$ niperion excelsae-foetidissimae. $\mathrm{V}$ prispevku je prikazan veljaven opis zveze v skladu z mednarodnim kodeksom fitocenološke nomenklature. Osnova za veljaven opis zveze je tudi veljaven opis nove asociacije - Querco trojanae-Funiperetum excelsae. Zvezo funiperion excelsae-foetidissimae smo nadalje uvrstili v red Quercetalia pubescentis Klika 1933 (Quercetea pubescentis Doing-Kraft ex Scamoni et Passarge 1959).

Ključne besede: gozd, Funiperion excelsae-foetidissimae, nomenklatura, Quercetea pubescentis, vegetation, vzhodno Sredozemlje.

Abbreviation and nomenclature:

DBH - diameter at breast height; ICPN - International Code of Phytosociological Nomenclature, $3^{\text {rd }}$ ed. (Weber et al. 2000); nomenclature of plant species follows Flora Europaea (Tutin et al. 1964-1980).

\section{INTRODUCTION}

In course of compilation of a checklist of highrank syntaxa of Europe (Mucina et al. in prep.), we have found that the funiperus excelsa forests occurring in the southern regions of the Balkan
Peninsula were not classified within a validly (according to the ICPN; Weber et al. 2000) described syntaxon. The name funiperion excelsae-foetidissimae, used to accommodate this type of vegetation in the past (e.g. Jovanović et al. 1986, Rodwell et al. 2002), turned out not to be validly published.

\footnotetext{
${ }^{1}$ Institute of Biology, Faculty of Natural Sciences, University of Ss. Cyril and Methodius University in Skopje, Skopje, Macedonia;

${ }^{2}$ Institute of Biology, Scientific Research Centre of the Slovenian Academy of Sciences and Arts, Ljubljana, Slovenia;

${ }^{3}$ University of Nova Gorica; Nova Gorica, Slovenia;

${ }^{4}$ Department of Environment \& Agriculture, School of Science, Curtin University of Technology, Perth, Australia.

* Corresponding author: carni@)zrc-sazu.si
} 
This short contribution is aimed at presenting the valid description of the funiperion excelsaefoetidissimae as well as of its nomenclatural type - the Querco trojanae-funiperetum excelsae.

\section{VALIDATION AND DESCRIPTION OF SYNTAXA}

\section{Funiperion excelsae-foetidissimae Em ex Matevski et al. all. nova hoc loco}

Synonyms: Funiperion excelsae-foetidissimae Em 1985 (phantom name); "Juniperion excelsae-foetidissimae Em in Jovanović et al. 1986" (art 2b; nomen nudum)

Character species: Funiperus excelsa, J. foetidissima Differential species: Rhamnus rhodopeus

Holotypus hoc loco: Querco trojanae-funiperetum excelsae (for the protologue of this association see below)

funiperus excelsa (Cupressaceae) is a tall shrub or tree up to $20 \mathrm{~m}$ tall, with a trunk as large as $2 \mathrm{~m}$ in diameter (at DBH level). Its crown is conical, but later it becomes broader and open. $f u$ niperus excelsa is an East Mediterranean element (see Jalas \& Suominen 1973: Map. 192) and can be found also in sub-mediterranean regions of southern Europe, namely in Albania, Macedonia, Bulgaria, and Greece. In Macedonia it is found on limestone gravel, serpentine and other types of bedrocks supporting shallow soils in warm habitats at altitudes 100-1200 m (Micevski 1985, Farjon 2005). In these regions funiperus excelsa forms locally open forests, which show different floristic composition from those described from Asia Minor (Quézel et al. 1980, Türe et al. 2005) and Crimea (Jakucs 1960, Didukh 1996, Vasylenko et al. 2009). The funiperus excelsa dominated forests have been classified into following syntaxa: the Quercion calliprini (Quercetalia ilicis, Quercetea ilicis) by Quézel et al. (1980) in N Anatolia; the Quercion anatolicae (Querco-Carpinetalia orientalis, Quercetea pubescentis) by Türe et al. (2005) in NW Anatolia, and the Funipero excelsae-Quercion pubescentis (Fraxino orni-Cotinetalia, Quercetea pubescetis) by Jakucs (1960) or the Fasmino fruticantis-funiperion excelsae (Fraxino orni-Cotinetalia, Quercetea pubescetis) by Solomakha (1995), Didukh (1996) and Vasylenko et al. (2009), both latter from Crimea.
All these communities can be found in the regions characterised by submediterranean climate (dry period during summer, maximum of precipitation in the period from October to February, mild winter). The communities can be found mainly on southern aspect over shallow, skeletal soils derived from carbonate bedrock. These extreme ecological conditions, common to all communities dominated by funiperus excelsa, support development of forests dominated by coniferous vegetation in the zone of deciduous forest mainly dominated by zonal oak forests. The funiperus excelsa forests are of southern provenience (Quézel et al. 1980) and are considered to possess a relict character.

These open forests are built of only few woody species of which Funiperus excelsa, J. foetidissima, f. oxcedrus and Quercus pubescens are found frequently across all known localities. In addition, the Euxinian floral element (e.g. Colutea cilicica) is more pronounced in the east (in Crimea and Anatolia), whereas the studied Balkan communities have local endemic Rhamnus rhodopeus. The canopy in these communities is not dense, and hence many species from neighbouring grasslands are found in the understorey - serving as regionally important diagnostic species emphasising the distinction between regional funiperus excelsa alliances.

In the Balkan, the concept of the funiperion excelsae-foetidissimae was proposed by Em (in Jovanović et al. 1986) as "Juniperion excelsae-foetidissimae Em 1985". There is no publication dated 1985 by Em where this name would have been actually published and the proposal of the name in Jovanović et al. (1986) offers only a nomen nu$d u m$, hence the syntaxon has not been validly published (following the ICPN, $3^{\text {rd }}$ edition).

Jovanović et al. (1986); (see also Rodwell et al. 2002) suggested that the funiperion excelsaefoetidissimae should be classified within the EricoPinetea. Our preliminary field data suggest, however, that species of thermophilous deciduous forests outnumber those of the relict montane pine woods. An analogous borderline syntaxonomical case is that of the Fraxino orni-Ostryion distributed along the southern fringes of the Alps and sharing floristic and ecological similarities with the regionally well-represented class of Erico-Pinetea. Further south (in the Dinarides) this forest vegetation, however, undoubtedly belongs to the Quercetea pubescentis (Čarni et al. 2009).

The alliance of funiperion excelsae-foetidissimae 
is classified in the Quercetalia pubescentis Klika 1933 (the Quercetea pubescentis Doing-Kraft ex Scamoni et Passarge 1959).

As there is at present no validly published association classified with this alliance, and therefore a new association is described in the sequel:

\section{Querco trojanae-funiperetum excelsae ass. nova hoc loco}

Synonyms: "Funiperetum excelsae-foetidissimae Em 1962" (phantom name); funiperetum excelsae-foetidissimae Em in Jovanović et al. 1986 (art. 2b, nomen nudum)

Holotypus hoc loco: Table 1/relevé. 1, in this paper.

Em (in Jovanović et al. 1986) proposed the name "Juniperetum excelsae-foetidissimae Em 1962", however this name had not been used in his work published in 1962. The form of this name is suggesting that this association could correspond to the association here described as new. The name funiperetum foetidissimo-excelsae was later used by Türe et al. (2005) for an association described from the NW Anatolia. Since we cannot be sure that the Em's association (in Jovanović et al. 1986) matches the concept of the our new association exactly, and because of the fact that the name Funiperetum foetidissimo-excelsae had been already used by Türe et al. (2005) for another syntaxonomic contents, we decided to coin a new name - the Querco trojanae-funiperetum excelsae.

The stands of this association are found in well-insolated and warm habitats, having shallow soils derived from limestone bedrock. The extreme site conditions enable funiperus excelsa to outcompete Quercus trojana and other oak species that dominate the oak forests in the neighbouring area. The diagnostic species of this association are funiperus excelsa and funiperus foetidissima (both character species of the association) and funiperus oxycedrus (species with high frequency).

funiperus excelsa might have arrived to the Balkan Peninsula during a warmer period of early Pliocene when there was also land connection between Asia Minor and the Balkans. It survived the repeated climatic oscillations of the Pleistocene in a similar manner as did some token relicts such as Aesculus hippocastanum, Forsythia europaea, Haberlea rhodopensis, Ramonda serbica, $R$. nathaliae in refugial habitats (Médail \& Diadema 2009).
There were several other vegetation units characterised by dominating funiperus excelsa reported from Macedonia. Em (1962) suggested the Pruno webii-funiperetum excelsae Em 1962 (nomen nudum) from the southern Macedonia, and divided this association into two subassociations, such as the phillyridetosum and the celtidetosum. The former subassociation is found in lowlands, however with increasing altitude thermophilous species, such as Quercus coccifera, Phillyrea media and Prunus webii disappear. The latter subassociation can be found at higher altitudes (at about $900 \mathrm{~m}$ ). The stands of this syntaxon are found on the Golem Grad Island in the Prespa Lake. The same author (Em 1989) mentioned the Biaro-funiperetum excelsae to occur from the Golem Grad Island, however failed to provide any other data allowing comparisons with other funiperus excelsa communities. The short list of species Em (1962) presented to charcaterise Pruno webii-funiperetum and in 1989 does not allow any serious comparison with the new association Querco trojanae-funiperetum excelsae either. At this stage we can only state that the Querco trojanae-funipertum excelsae is differentiated from the lowland funiperus excelsae-dominated communities (such as the Pruno webii-funiperetum excelsae Em 1962) by presence of Quercus trojana, Q. frainetto, Q. cerris, and by lack of thermophilous species such as Carpinus orientalis, Paliurus spina-christi and Asparagus acutifolius.

\section{Syntaxonomical scheme}

Quercetea pubescentis Doing-Kraft ex Scamoni et Passarge 1959

Quercetalia pubescentis Klika 1933

Funiperion excelsae-foetidissimae Em ex Matevski et al. 2010

Querco trojanae-funiperetum excelsae Matevski et al. 2010

\section{ACKNOWLEDGEMENTS}

We owe our thanks to Dmito Yakushenko for providing some Ukrainian literature sources. The authors acknowledge the financial support from the state budget by the Slovenian Research Agency (Projects No. L1-9737 and P1-0236). We also thank the management of the Galičica National Park for logistic support. 


\section{REFERENCES}

Braun-Blanquet, J. 1964: Pflanzensoziologie. Grundzüge der Vegetationskunde. $3^{\text {rd }}$ ed. Springer, Wien, 865 pp.

Čarni, A., Košir, P., Karadžić, B., Matevski, V., Redžić, S. \& Škvorc, Ž. 2009: Thermophilous deciduous forests in southeastern Europe. Plant Biosystems 143: 1-13.

Didukh, Ya. 1996: The communities of the class Quercetea pubescenti-petraeae of the Crimean Mountains. Ucrain. Phytocoenol. Coll., Ser. A 1: $63-77$.

Em, H. 1962: Šumske zajednice četinara u NR Makedoniji. Biol. Glasn. 15: 1-21.

Em, H. 1989: Ist der verkahlende Zürgelbaum (Celtis glabrata Stev.) autochton auf der Insel Golem Grad im Prespa-See? Bios - Volume dedicated to prof. Konstatin Ganiatsas (Thessaloniki), pp. 65-66.

Farjon, A. 2005: A monograph of Cupressaceae and Sciadopitys. Royal Botanic Gardens, Kew, $643 \mathrm{pp}$.

Jakucs, P. 1960: Noveau classement cénologique de bois de chênes xérothermes (Quercetea pubescentis-petraeae cl. nova) de l'Europe. Acta Botanica Hungarica 6: 267-303.

Jalas J. \& Suominen J. 1973: Atlas florae europaeae. 2. Gymnospermae (Pinaceae to Ephedraceae). The Committee for Mapping the Flora of Europe and Societas Biologica Fennica Vannamo, Helsinki, 40 pp.

Jovanović, B., Lakušić, R., Rizovski, R. \& Zupančič, M. 1986: Prodromus phytocoenosum Jugoslaviae. Naučno veće vegetacijske karte Jugoslavije, Bribir-Ilok, 46 pp.

Médail, F. \& Diadema, K. 2009: Glacial refugia influence plant diversity patterns in the Mediterranean Basin. Journal of Biogeography 36: 1333-1345

Micevski, K. 1985: Flora na SR Makedonija 1 (1). MANU, Skopje, 152 pp.

Quézel, P., Barbero, M., Akman, Y. 1980: Contribution à l'étude de la végétation forestière d'Anaotolie septentrionale. Phytocoenologia 8: 365-519.

Rodwell, J.S., Schaminée, J.H.J., Mucina, L., Pignatti, S., Dring, J. \& Moss, D. 2002: The diversity of European vegetation. An overview of phytosociological alliances and their relationship to EUNIS habitats. EC-LNV, Report ECLNV 2002/054, Wageningen, 168 pp.

Solomakha, V.A. 1995: Sintaksoni roslinnosti
Ukraini za metodom Braun-Blanke ta ikh osobenosti. Naukove vydaniya biologichnogo fakultetu Nacjonal'nogo Kyyevskogo universitetu im. Tarasa Shevchenka, Kyyv, 116 pp.

Tutin, T.G., Heywood, V.H., Burges, N.A., Moore, D.M., Valentine, D.H., Walters, S.M. \& Webb, D.A., editors 1964-1980: Flora Europaea. Vols 1-5. Cambridge University Press, Cambridge.

Türe, C., Tokur, S. \& Ketenoğlu, O. 2005: Contribution to the syntaxonomy and ecology of forest and shrub vegetation in Bithynia, Northwestern Anatolia, Turkey. Phyton (Horn) 45: 81-115.

Vasylenko, S.M. \& Kuzmanenko, O.L. 2009: Characteristic of the Funiperus excelsa Bieb. population of Kyzyltash (Southern-eastern Crimea): density, age structure, phytosociological and ecological features. Chornomors'k. Bot. Zh. 5: 98-106.

Weber, H.E., Moravec, J. \& Theurillat, J.-P. 2000: International Code of Phytosociological Nomenclature. 3rd edition. Journal of Vegetation Science 11: 739-768.

Received 24. 2. 2010

Revision received 2. 3. 2010

Accepted 5. 3. 2010

\section{Table 1}

Relevé 1. Macedonia, Magarino, below Sirhansko Kale Hill (4100'03.0" N, 205'23.3" E), 23-062009, altitude: $1046 \mathrm{~m}$, inclination: $40^{\circ}$, aspect: WSW, plot size: $100 \mathrm{~m}^{2}$, no stone on surface, cover of tree layer: $70 \%$, cover of shrub layer: $60 \%$, cover of herb layer: $20 \%$, cover of moss layer: 2 \%. Authors: M. Kostadinovski, U. Šilc. (holotypus of the association)

Relevé 2. Macedonia, Magarino, below Sirhansko

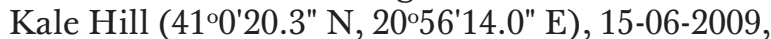
altitude $903 \mathrm{~m}$, inclination: $12^{\circ}$, aspect: EES, plot size: $100 \mathrm{~m}^{2}$, stoniness: $1 \%$, cover of tree layer: $90 \%$, cover of shrub layer: $90 \%$, cover of herb layer: $40 \%$, cover of moss layer: $10 \%$. Authors: M. Kostadinovski, A. Marinšek, U. Šilc. 
Relevé 3. Macedonia, Magarino, below Sirhansko Kale Hill (4100'22' N, 2055'50” E), 17-06-2009, altitude: $1118 \mathrm{~m}$, inclination: $30^{\circ}$, aspect: ESE, plot size: $100 \mathrm{~m}^{2}$, stoniness: $30 \%$, cover of tree layer: $30 \%$, cover of shrub layer: $90 \%$, cover of herb layer: $95 \%$; no moss layer. Authors: A. Čarni, V. Matevski, A. Paušič.

Species with only one occurrence in the table (herb layer):

Rel. 1. Fragaria moschata 2, Ventenata dubia 1, Campanula spathulata subsp. spruneriana + , Clinopodium vulgare +, Galium aparine +, Geranium lucidum ,+ Helleborus odorus + , Pilosella vulgaris agg. +, funiperus oxycedrus (juv.) +, Lathyrus sphaericus + , Phleum phleoides + , Trifolium cherleri + , Trifolium dalmaticum + , Trifolium phleoides + , Trifolium pratense + , Vicia cracca +, Vicia onobrychoides +

Rel. 2. Geranium robertianum subsp. purpureum 1, Trifolium scabrum 1, Arabis turitta + , Aremonia agrimonioides +, Bellis perennis + , Centaurea grisebachii +, Clematis vitalba +, Draba muralis +, Galium tricornutum + , Hieracium praealtum subsp. baucinii +, Hypericum perforatum +, Iris sintenisii +, Leontodon crispus subsp. crispus +, Lonicera xylosteum (juv.) +, Orchis morio +, Poa trivialis subsp. sylvicola + , Quercus pubescens (juv.) +, Taraxacum officinale agg. +, Tragopogon pratensis +

Rel. 3. Carex halleriana 3, Anisantha tectorum 1, Stipa bromoides 1, Aethionema saxatile + , Alyssum trichostachyum subsp. stenophyllum +, Anthyllis vulneraria subsp. macedonica + , Arabis hirsuta + , Turritis pseudoturritis +, Arenaria serpyllifolia +, Asperula purpurea + , Buglossoides incrassata + , Bupleurum flavicans +, Caucalis daucoides +, Coronilla scorpioides +, Geranium dissectum + , Helianthemum salicifolium + , Helichrysum plicatum +, Hypericum rumeliacum subsp. blepharophyllum + , Iris attica + , Koeleria splendens + , Lathyrus cicera + , Linum austriacum + , Medicago rigidula + , Melica ciliata + , Minuartia hybrida + , Nigella damascena + , Ophyris apifera + , Oryzopsis virescens + , Pimpinella tragium subsp. lithophylla +, Scandix australis + , Sedum acre + , Steptorhamphtus tuberosus +, Thymus tosevii +, Trifolium campestre +, Verbascum sp.+, Xeranthemum annuum +

Species with only one occurrence in the table (moss layer):

Rel. 1. Musci indet. +

Rel. 2. Pleurozium schreberi 1
Table 1: Relevé table of the Querco trojanae-Juniperetum excelsae. The abundance-dominance sampling scale follows Braun-Blanquet (1964).

Tabela 1: Vegetacijska tabela asociacije Querco trojanae-Juniperetum excelsae. Skala prisotnosti in pokrovnosti je v skladu z Braun-Blanquet (1964).

\begin{tabular}{lll}
\hline Relevé number & 1 & 2 \\
\hline
\end{tabular}

Tree layer $\left(\mathrm{E}_{3}\right)$ :

Juniperus excelsa

Juniperus foetidissima

Quercus frainetto

Clematis vitalba (liana)

Shrub layer $\left(\mathrm{E}_{2}\right)$ :

Juniperus oxycedrus

Quercus trojana

Lonicera etrusca

Rosa sp.

Juniperus excelsa

Rhamnus rhodopeus

Prunus spinosa

Quercus frainetto

Quercus pubescens

Quercus cerris

Rubus canescens

Cornus mas

Fraxinus ornus

Herb layer $\left(\mathrm{E}_{1}\right)$ :

Dactylis glomerata ssp . hispanica

Medicago minima

Sanguisorba minor ssp. muricata

Acinos alpinus ssp. meridionalis

Brachypodium sylvaticum

Geum urbanum

Lonicera etrusca (juv.)

Myosotis arvensis

Potentilla laciniosa

Thymus longicaulis

Trifolium physodes

Poa bulbosa

Cerastium brachypetalum

Geranium robertianum ssp. purpureum

Veronica chamaedrys

Carduus thoermeri

Crupina vulgaris

Eryngium campestre

Crucianella angustifolia

Teucrium chamaedrys

Scabiosa fumarioides
2

$+$

$+$

4

$+$

$+$

1

1

$+$

$+$

$+$ $+$ 